\title{
Motiv identitete v romanih Frančiška in Prijateljstvo pisatelja Fulvia Tomizze
}

\author{
Maja STARC \\ Križ 245,6210Sežana,SI-Slovenija, starc.maja@gmail.com
}

\begin{abstract}
SCN VI/1 [2013], 98-111
Motiv identitete, predvsem obmejne identitete, ima v romanih pisatelja Fulvia Tomizze pomembno mesto, saj mu kot pisatelju meje, kot se je sam imenoval, predstavlja rdečo nit v življenju in delu na literarnem področju. V romanih Prijateljstvo in Frančiška se zaradi njegove dvojne identitete pokaže njegova sposobnost objektivnega vrednotenja skupin ljudi, ki se v določenih posebnih okoliščinah znajdejo v podrejenem oz. nadrejenem položaju. Razprava skuša pokazati pisateljev human čut do ljudi, ki se znajdejo v manjšinskem položaju, in njegovo literarno zavzemanje za boljše odnose med italijanskim in slovenskim narodom.
\end{abstract}

The motif of identity, especially border identity, has an important place in the novels of the writer Fulvio Tomizza, because as a border writer, as he called himself, it represents a leitmotif in his life and literary work. Because of his double identity the novels Prijateljstvo and Frančiška reveal his capacity of objective evaluation of groups of people who find themselves in a subordinate or superior position in certain circumstances. The discussion tries to show the writer's humane sense for people who find themselves in a minority position and his literary commitment to better relations between the Italian and Slovenian nation.

Ključne besede: obmejna identiteta, Fulvio Tomizza, Prijateljstvo, Frančiška, manjšinskost

Key words: border identity, Fulvio Tomizza, Prijateljstvo, Frančiška, minority

\section{Uvod}

Motiv identitete je lahko zelo široko pojmovan, vendar se bomo v razpravi omejili na obravnavo obmejne identitete, torej na problem bivanja $v$ določenem prostoru. Nestrpnost do drugačnih je pogosta tema predvsem pri piscih 
iz mejnih ali katerih drugih etnično mešanih območij, kot je v našem primeru tržaško območje. Na teh predelih se lažje rojevajo konflikti interesov. Ljudje včasih nimajo svobodne možnosti izbiranja lastne identitete. Ko se od ljudi zahteva, da se opredelijo, pogosto izbirajo med dvema možnostma. Nekateri svojo identiteto iz strahu pred nasiljem zatajijo, a tako za vedno izgubijo zvestobo do sebe in drugih. Tisti, ki vztrajajo pri resnici in svojih pravicah, pa se morajo sprijazniti z usodo podrejenosti večini, torej z manjšinskostjo. Mnogi med njimi so zbrali pogum in svojo izkušnjo ubesedili v literarnih besedilih. Tako to počnejo v Trstu in njegovi okolici na primer Boris Pahor, Alojz Rebula, Evelina Umek, Miroslav košuta, Marko Kravos, Alenka Rebula Tuta, Dušan Jelinčič in drugi. Med pisci pa zaradi svoje italo-slovanske identitete, ki si jo je prislužil kot priseljenec iz Istre, izstopa istrski pisatelj Fulvio Tomizza. Kljub možnosti, da bi se v preteklosti opredelil za čisto italijansko identiteto in se tako izognil številnim nevšečnostim, je vztrajal, da ima dvojno identiteto in da je treba pripadnike večine in manjšine obravnavati enakovredno.

V razpravi bomo izpostavili dve njegovi deli, in sicer romana Prijateljstvo in Frančiška. Iz njegovega širokega opusa izstopata predvsem zaradi posebne obravnave identitete dveh vrst Italijanov in identitete Slovencev v Trstu ter na Krasu. K obravnavi nas je prepričal s poudarjanjem strpnosti oz. sprejemanjem ljudi z drugačnim jezikom ali drugačno kulturo. S ponavljanjem zastarelih fraz in predsodkov onemogočamo varen obstoj tako manjšine kot tudi večine. Manjšine zaradi stalnega ustrahovanja in onemogočanja njene popolne uveljavitve, večine pa, ker se zaradi strahu pred zamenjavo vlog, torej da jim položaj večine zdrsne $\mathrm{v}$ podrejenost, stalno ukvarjajo z učinkovito obrambo namesto $\mathrm{z}$ napredkom.

Poleg kolebanja med opredeljevanjem narodnosti se $\mathrm{v}$ obravnavanih romanih pojavlja tudi motiv neodločnosti ostati podeželan ali postati meščan, kar pa je seveda spet $\mathrm{v}$ tesni povezavi z biti Slovan (Slovenec in Hrvat) ali biti bolj Italijan.

Pojem identitete je širok in večplasten, zato bom v nadaljevanju na kratko predstavila teorijo identitete po monografiji Identiteta avtorja Staneta Južniča.

\section{Teorija identitete po Južniču}

Je sidrišče človekovega obstajanja, ki mu lahko rečemo tudi kar pripadanje. Gre za opredeljevanje človekove ukoreninjenosti v njem samem, v družbi in kulturi, v kateri se kot človeško bitje uresniči (Južnič 1993: 5). Pojem identiteta izhaja iz srednjeveške latinščine. Slovenska beseda bi bila istovetnost. Avtor govori o različnih identitetah. Najprej pa jo razdeli na dve večji skupini, in sicer na osebno identiteto, ki je sestavljena iz avtoidentifikacije. To je tista identiteta, ki si jo posameznik pripiše sam. Drugi del osebne identitete pa je tista, ki mu jo pripiše družba (Južnič 1993: 11).

Identiteto deli v štiri večje skupine: identificiranje s telesom, osebna ter skupinska identiteta, kulturna identiteta, zadnja skupina pa je etničnost in nacionalna identiteta (Južnič 1993: 11-14). 
V primeru obravnave literarnih del Fulvia Tomizze je telesna identiteta nepomembna. Konflikti med Slovenci in Italijani na tem območju se namreč rojevajo predvsem zaradi drugačnih razlik. Pripadniki obeh skupin se ne ločujejo po barvi kože, kot je to npr. značilno za prebivalce Združenih držav Amerike. Prebivalce Trsta in okolice določajo drugačne posebnosti. Pri obravnavi identitete zato pridejo $\mathrm{v}$ poštev skupinska, kulturna in nacionalna identiteta ter etničnost. Slednje bomo predstavili po Južničevi monografiji.

V okviru identifikacije s skupino se lahko v določenem okolju razvije pojav stigmatizacije. Sicer je lahko stigmatizirana vsaka vrsta drugačnosti. V teh primerih se pokaže krivda, ki prizadene nedolžnega. Takšnih kolektivnih predstav o neutemeljenih krivdah je veliko. Eden od primerov je prepričanje kristjanov v krivdo judov za križanje in smrt Jezusa Kristusa (Južnič 1993: 123-124).

Posebno vrsto identitete oblikuje marginalizacija. Lahko gre za skupino v tujem okolju, ki se trdo drži lastnih navad in vrednot. Marginaliziran je lahko tudi vsakdo, ki se odločno ne opredeli za pripadanje določeni skupini in ne ločuje na svoje in druge. Marginalizacija je še posebej prisotna v velikih mestih, kamor se priseljuje veliko različnih ljudi. Ti in njihovi potomci se nikoli ne počutijo popolnoma sprejete (Južnič 1993: 125-129).

Priseljenci se včasih želijo zliti z novim kulturnim okoljem, zato sprejmejo novo kulturo, si spremenijo ime ipd. V določenih okoliščinah lahko neka skupnost imena prisilno spreminja (Južnič 1993: 190). Večji odklonilen odnos do neke skupine ljudi se doseže z zmerjanjem. V času fašizma so Slovence zmerjali s ščavi (Južnič 1993: 198-200). V besedilih italijanske poezije prve polovice 20. stoletja se za označitev Slovencev pojavljata poleg izraza s'ciavo še izraza pipa in crico (Toroš 2011: 71). V vsakdanjem življenju Trsta se za poimenovanje Slovencev in drugih Slovanov pogosto še vedno sliši slavi in s'cavi, za vse temnopolte prebivalce mesta pa marokini. Marta Ivašič (2010: 37) ugotavlja, da je to način poimenovanja nedoločenega naroda brez natančne identitete. Včasih se sliši slavi tudi za Albance in Romune.

Etničnost kot identiteta je določena $\mathrm{z}$ rojstvom $\mathrm{v}$ določeni etnični skupini (Južnič 1993: 268). Velike težave nastanejo pri določanju etničnih meja in skoraj praviloma so etnične meje sporne. Pri ustanavljanju držav se pogosto zahteva etnično homogenost, kar lahko privede do etničnega čiščenja (Južnič 1993: 274-275). Središčni pomen pri oblikovanju etnije ima jezik. Še posebej lahko pomeni neko ločnico med sosednjimi etnijami ali narodi, če je ta kontrasten. Težave opredeljevanja, kateri etniji posameznik pripada, se povečajo pri prebivalcih na jezikovnih robovih. Od njih se pričakuje, da se opredelijo jezikovno in tudi politično (Južnič 1993: 280-281).

\section{Obmejna identiteta}

Obmejna območja so zaznamovana s specifičnim občutenjem svoje biti. Večini ljudi, ki ne živi ob meji, se ni potrebno obremenjevati z lastnim opredeljevanjem; odgovor na vprašanje $k d o$ sem, se jim zdi samoumeven. Povsod obsta- 
jajo razlike med ljudmi, vendar pa razlike in konflikte na obmejnih območjih določa posebna obmejna identiteta. Življenje ob meji bi sicer lahko teklo brez posebnosti, a se ob tamkajšnjih domovih potuhnjeno riše glasna ločnica, ki zahteva izpostavljanje minimalnih razlik do drugačnih.

Obmejno področje z opisano problematiko je tudi severovzhodni Jadran, torej Istra in Tržaška pokrajina, kjer je zaradi stika različnih kultur prihajalo do pogostih političnih sprememb. Prav tržaški iredentizem je povzročil začetek diferenciacije tudi v Istri. Politične odločitve so pred 2 . svetovno vojno ta svet razkrojile in zahtevale homogenost na vsaki strani meje. Teoretiki 19. in 20. stoletja so družbene in kulturne meje želeli uskladiti s političnimi mejami. Zarisale so se meje, ki so sprožile nemire.

Politični interesi so prevladali nad interesi ljudi, ki ob mejah živijo in jih ne dojemajo enako kot politika centrov. Meje so zanje ovire, ki jih ločujejo od sorodnikov, virov preživetja in ustaljenih poti. Politika je zahtevala enotno skupinsko identiteto, vendar pa to za te ljudi pomeni zanikanje samega sebe. Ko politiki uspe oblikovati vzorce o večvredni oz. manjvredni identiteti, se v ljudeh vzbudi potreba po poudarjanju svojih posebnosti in razlik z drugačnimi.

V Istri je od nekdaj živela večinoma tradicionalna kmečka družba z enako vero, torej s katoliško veroizpovedjo, s skupno zgodovino in s skupnim jezikom. Njihov jezik je mešanica slovanskega, italijanskega in beneškega narečja, je bistvo vseh Istranov, ki jim daje posebno skupinsko identiteto. Je tro-enojna duša, ki je do prihoda nacionalizma nihče ne bi zanikal. Tudi Tomizza je na vprašanje, ali je bolj Italijan, Slovenec ali Hrvat, odgovarjal, da je vsakega malo, namreč Istran. Priimek naj bi se v dokumentih pisal z dvema italijanskima $z$ že od leta 1660, njegov oče pa je doma govoril v slovanskem narečju. Nekatere besede so zvenele tipično hrvaško, druge pa tipično beneško (Stella 1992: 12).

Ugotovimo lahko, da imajo ljudje na stičišču velikih držav, kultur in jezikov posebno identiteto in tako je tudi v Istri. Prav ta nedoločljivost je njihova posebnost. Tudi Tomizza je vedno govoril, da se identificira z mejo. Ta specifika je bila bolj prisotna pred pojavom eksodusa, saj je po njem in še bolj po ustanovitvi republik Slovenije in Hrvaške Istra dobila drugačno nacionalno podobo.

\section{Vprašanje nacionalne in socialne identitete v romanu Frančiška}

Čeprav se skozi zgodbo na videz najopazneje razvija ljubezenska tematika med Italijanom iz Cremone in Slovenko iz Štanjela, ima vprašanje identitete pri glavnih literarnih likih prav tako velik pomen, če ne največji. Gre za zgodbo, ki temelji na resnično obstoječih pismih, in tudi zgodovinske okoliščine so resnične. Ljubezenska zgodba je predvsem okvir za nazorni prikaz burnega tržaškega življenja med vojnama. V zgodbi je izpostavljeno nasprotje med biti Slovenec ali biti Italijan.

Inženir Nino je po italijanskem zavzetju Tržaške pokrajine z Istro dobil službene zadolžitve v Trstu. Prihajal je iz premožne družine industrijcev. Družina mu je nudila varnost in denar, da je lahko v miru študiral in se po- 
svečal svojim ljubeznim: umetnosti, potovanjem ... Frančiška je bila njegovo nasprotje. Prihajala je iz revne kmečke družine. Oče vdovec je bil mizar, ona pa je morala že od rane mladosti poprijeti za vsako delo. Deloma ji je mamo nadomestila nesebična teta Mila. Živeli so v revščini, zaradi česar si Frančiška ni mogla omisliti kvalitetnega šolanja. To je bila tudi ena temeljnih razlik med njo in mestno vzgojenim Ninom. Četudi sta ga njena skromnost in iskrenost na začetku silno prevzeli, mu je kasneje njena vaška preprostost postala nadležna. Ko sta se zaradi Ninove bolezni ločila in ohranjala stik le še prek pisem, se je njegova ljubezen ohladila. V njej je skopnela dragocena in nesebična čustvena vnema, nadomestila pa jo je dvomljiva razumska miselnost, ki je v njegovih pismih zajemala vse več prostora. Frančiškina preprosta nezahtevnost mu je postala v napoto. Tudi pri iskanju najprimernejših besed se je vse bolj spotikal ob njene trdožive kmečke korenine.

Že na začetku dvorjenja Frančiški je bila njegova naklonjenost skromnim in preprostim vprašljiva. O tem je premišljevala tudi Frančiška, saj je večkrat poudarjal, da ne mara bogatih in vzvišenih, kaj kmalu pa si je premislil in se hvalil s svojim bogastvom. Dvomi so postali postranska stvar. Frančiška se $\mathrm{mu}$ je popolnoma predala $\mathrm{v}$ mislih in dejanjih. Ničesar ni zahtevala, njegove na začetku skromne zahteve pa so se ji zdele nekaj povsem naravnega in jih ni sprejemala kot naporne. Vse v imenu ljubezni. Nino pa je postajal vse bolj preračunljiv in zahteven. Razlika v socialni pripadnosti je postajala vse bolj nesprejemljiva. Nekoč, ko se je sam verjetno na tihem že odločil za prekinitev razmerja, ji je v pismu neusmiljeno zapisal:

Si ti zamišljaš moje sorodnike /.../: vsi so bogati /.../, ko bodo izvedeli, da bo eden izmed njih - prav jaz, ki sem najbistrejši /.../ poročil ubogo dekle, kot si ti? Mizarjevo hčerko? Dekle, ki se preživlja $\mathrm{z}$ delom /.../, namesto da bi hodila plesat, $\mathrm{v}$ gledališče /.../, prav on, tako inteligenten, tako izobražen, ti izbere za ženo mizarjevo hčerko? Res, očitno je znorel! In ko bo postala njegova žena, kako bomo sprejeli tisto razcapanko /.../? (Tomizza 2002: 125-126)

Naslednje nasprotje je narodnostno. V času rojevajočega se in vse krepkejšega fašizma v Trstu so bile pri snovanju nasprotnika pomembne razlike med ljudmi in edina oz. glavna razlika je bila narodna pripadnost in posledično jezik.

Tudi zaradi drugačne narodne identitete se je morala Frančiška velikokrat brzdati in krotiti prizadetost. Na delovnem mestu v Trstu so sodelavci večkrat izražali nestrpne misli do tržaških Slovencev. Frančiška je sodbe čutila kot osebno žalitev, saj se je z vsem srcem čutila Slovenko. Frančiški se je v danih razmerah zdelo dopustno, da s sodelavci in Ninom govori italijansko, zato se je ves čas tudi trudila, da bi jezik izboljšala. To je zahteval tudi Nino. Ko se je namreč zavedal, da utegne Frančiška postati njegova žena, jo je pri govoru ves čas popravljal in opominjal, da se mora še bolj potruditi. Svetoval ji je celo učne ure italijanskega jezika. Skrbelo ga je, da bi njena italijanščina, obarvana s slovenskim naglasom, izdajala Frančiškino narodno pripadnost.

Zavračal je njeno socialno in narodno identiteto, izničil njen jezik, čeprav vse posredno in prefinjeno, preko nasvetov ter svaril, ki pa so se sčasoma 
prelevila v vztrajne zahteve. Njene drugačnosti se je zbal. Njena preprostost ga je privlačila, a mu je trdoživa meščanska miselnost ves čas sugerirala, da je biti preprost enako biti kmet, biti neizobražen, celo neroden, skratka biti nesprejemljiv za njegov petični svet. Frančiška se je vseh pogojev zavedala in se tudi trudila, da bi jih izpolnila po najboljših močeh. Kupovala si je lepa oblačila, se urejala, izboljševala znanje italijanskega jezika. Ko se je vrnila s počitnic ob morju, je zaradi narodne pripadnosti izgubila službo. Kmalu je prejela tudi zadnje Ninovo pismo, kjer ji je surovo napovedal, da se umika iz njenega življenja.

\subsection{Metafora neuresničene ljubezni}

Miran Košuta (2002: 40) ugotavlja, da je neodločna ljubezen med Ninom in Frančiško nekakšna metafora za odnos med Italijani in Slovenci nasploh.; je kot »nesojena ljubezen med dvema narodoma, kulturama, jezikoma, ki soživljata že več kot tisočletje na alpsko-jadranskem limesu, pa se še nista zmogla zaljubiti drug v drugega, ali vsaj spremeniti svojega sosedstva v resnično plodno medkulturno simbiozo«. Metafora pa je še kako živa v sodobni stvarnosti. Nestrpnosti zaradi identifikacijskih razlik je veliko tako na meddržavni kot tudi osebni ravni intimnih zgodb, kar kaže, da še danes deluje prikriti nacionalizem, ki ne dovoljuje biti drugačen. $\mathrm{V}$ podzavesti Tržačanov tli stalna pripravljenost, da te ob prevelikem izražanju svoje drugačne identitete opozarja, da je varneje, če se na tihem zlivaš z večino. Tako v svoji raziskavi ugotavlja tudi Majda Kaučič Baša (2007: 206): »Tudi slovenski zasebniki, ki sicer radi govorijo slovensko, izobesijo slovenski napis le izjemoma, vzrok za to je strah pred javnim razkrivanjem slovenščine, ki ga je vcepil fašizem, današnje razmere pa ga oživljajo.«

\section{Vprašanje nacionalne in socialne identitete v romanu Prijateljstvo}

\subsection{Nasprotje Marco - Alessandro}

Temeljna razlika med literarnima likoma je, da je Alessandro rojen Tržačan, Marco pa prišlek iz Istre. Ezuli ali optanti med Tržačani nikoli niso bili sprejeti kot njim enakovredni. Kljub temu da so se številni zaradi politične situacije opredelili za čiste Italijane, so tržaškim Italijanom dišali po mešancih in jim niso nikoli popolnoma zaupali. Zaradi občutka prevare se je tudi med tržaškimi Istrani rojevala nestrpnost. Marco pa ni nikoli prestopil na stran nestrpnežev. Poslabšanje življenjskega standarda in občutje tujosti se nista prelevila v gnev in sovraštvo do Slovanov. Znal je biti natančen in opazil je, da so tudi Slovenci v nezavidljivem položaju. S tem je Marco ostal zvest tudi svoji izvorni identiteti, saj je biti Istran v resnici pomenilo imeti vse tri identitete. Alessandro pa je bil tog v svojih prepričanjih in zanj so bili Slovani inferiorni. Svojega mnenja ni znal prepričljivo utemeljiti. Slonelo je na vsesplošnem povojnem sovraštvu do 
vsega, kar je namigovalo na komunizem. Alessandro se tudi ni nikoli znašel v položaju zatiranega in nikoli ni občutil tovrstne stiske. Do takih tem je ostajal malomarno apatičen. Kadar je izražal svoje mnenje o Slovencih, je le citiral obrabljene tržaške fraze. Brez pretirane čustvene nabitosti, brez vsebinske obremenjenosti. Zanj so bila to dejstva, predsodki, ki nanj niso imeli velikega vpliva, zato se z njimi ni imel namena obremenjevati. Ravno zaradi takega odnosa do nečistokrvnežev je prijateljstvo ostajalo le površinsko. Marco se v Trstu še dolgo ni počutil sprejetega. Trenutkov, ko je zaradi svoje identitete klonil pod težo italijanske vzvišenosti, je bilo veliko. Marco je opazil, da se ga je Alessandro v položajih, ko se je razkrila Marcova nečista identiteta, sramoval. Alessandro se je bal, da bi si zaradi prijateljstva z Marcom zmanjšal tudi svojo vrednost $\mathrm{v}$ družbi.

Drugi identifikacijski element, ki je razločeval Marca od Alessandra, je socialna pripadnost. Alessandro je rojen meščan, materialno preskrbljen s stalno zaposlitvijo kot bančni uslužbenec, Marco pa človek kmečkega okolja, z željo postati meščan, a brez stalnega zaslužka. Končni vstop v meščanski svet si je priskrbel s poroko Judinje Cinzie, katere oče je bil upokojeni univerzitetni profesor. Ko je prvič vstopil v njihovo hišo, se mu je zdelo, kot da so ga poklicali na sodišče za mladoletne. Vajenega domače skromnosti je bogato urejena patricijska hiša očarala. Tudi Cinziin oče se mu je zdel mogočen. Pred njim mu je bilo zelo nerodno. Profesor je izvedel za Marcov literarni uspeh, a ker ju še ni poznal, je po intuiciji predvideval, da je nagrajenec Alessandro, in mu čestital. Marcu je pobil še tisti kanček samozavesti, ki ga je premogel: »Spet sem padel v italijansko poloblo, kjer mi je moj na pol kmečki na pol slovanski rod nemudoma spodnesel noge« (Tomizza 1981: 105). V prvih dneh spoznavanja se je sicer še vedno čutil tujca v Cinziini družini, sčasoma pa se je udomačil in Cinziini starši so ga sprejeli za svojega. S Cinziinim očetom sta pogosto imela pogovore o literaturi in drugih abstraktnejših temah. Ravno to je bila dragocena meščanska nota, ki si jo je Marco želel pridobiti. Skozi izmenjavo mnenj je izpopolnjeval svoja prepričanja in znanja. V mestu se je začel čutiti bolj sprejetega. Med drugim je dobil tudi stalno zaposlitev na radiu.

Kljub temu da si je opomogel in se povzpel tudi po družbeni lestvici, je v sebi ohranil skromnost. Z Alessandrom sta vse pogosteje zahajala na Kras med Slovence. Kraško kmečko okolje mu je pomenilo nadomestek za domačo Istro. $\mathrm{Na}$ Krasu se je ponovno počutil sprejetega. Njegova slovanska identiteta tam ni bila nikomur $\mathrm{v}$ napoto. Znal je tudi slovensko in $\mathrm{z}$ domačini se je rad pogovarjal v njihovem jeziku. Med njimi se je počutil doma, čeprav je ta svet le obiskoval in občudoval, sam pa se je kot vedno bolj uveljavljen literat bolj znašel v mestnem načinu življenja. Alessandro pa na Krasu ni občutil nič navdihujočega. Tja je zahajal le zaradi dobre hrane in Irene, ki mu je postajala všeč. Slovenske pristnosti, ustrežljivosti, delavnosti in preprostosti pa ni cenil. Te lastnosti so mu predstavljale vrline podrejenih, manjvrednih in nekaj samoumevnega. Med Slovenci sta se njegova in Marcova vloga zamenjali. Marcu se je uspelo zliti z okoljem in se počutiti popolnoma sprejetega, Alessandra pa se je držalo občutje tujstva. Le da si je tako občutje prislužil zaradi svoje samovšečnosti in 
vzvišenosti. Marco pa se v Trstu ni znašel ravno zaradi nasprotnega občutja in svoje skromnosti. V njem je pogrešal iskrenost in preprostost. Alessandru pa je bila že vsaka vrsta drugačnosti moteča. Preveč kmečki in nekultiviran se mu je zdel celo slovenski jezik. Zavračal je kakršno koli udomačitev v novem svetu, tako je ostajal zunaj njega in ga opazoval z nadrejenega položaja kot tujca.

\subsection{Nasprotje med Cinzio in Ireno}

Nasprotje je podobno kot pri prejšnji dvojici, gre za nasprotje med vaško preprostostjo in mestno vzvišenostjo, čeprav je veliko razlik. Irena je Slovenka iz kmečkega okolja, čeprav ne ravno ena povprečnih. Doma imajo namreč donosno vaško gostilno. Ko se zaljubi v Alessandra, ga sprejme za sebi enakega. Kljub temu da so Slovenci na tem področju še pred kratkim trpeli fašistično nasilje, je njegova nacionalna pripadnost ni motila. Krivde za vse bolečine in krivice ni posploševala na vse Italijane. Cinzia je Alessandru podobna po svoji vzvišenosti zaradi svojega meščanskega porekla. Ne obremenjuje se z Irenino nacionalno pripadnostjo, saj tudi sama pripada diskriminirani in preganjani skupnosti v Trstu in ve, kaj pomeni biti Neitalijan v Trstu, moti pa jo njena kmečkost. Z njo se sicer pogovarja, vendar samo zato, da bi s tem ustregla možu Marcu. Alessandrovo in Cinziino mestno poreklo se je omejevalo na pasivnost in zadržanost. Sprejemala sta le svoj svet. Drugačnost ju ni navduševala in presenečala. Vztrajna pasivnost pa je Ireno ohlajala in začela se je ozirati za drugim moškim, narodnim aktivistom, odvetnikom Vilharjem. Iz svoje notranjosti je kljub navidezni preprostosti izžarevala željo po spremembah, po prihodnosti, napolnjeni z aktivno vsebino. Bila je tudi odločna in pogumna ženska. Cinzia in Alessandro sta jo zaradi kmečkega porekla ves čas podcenjevala. Sčasoma se je pokazalo, da pripadnosti kmečkemu svetu ne gre enačiti z zanemarjanjem uma oz. intelekta. Alessandro je naivno predpostavljal, da ga Irena ceni prav zaradi njegove narodnosti in meščanskosti, ki naj bi vsebovala neko samoumevno plemenitost ter da ji izobrazba ne pomeni odlike. Šolanja, ki ga je začela, namreč ni zaključila. Ko pa je vse pogosteje začela zahajati k Vilharjevim, se je tam navzela tudi višjih vrednot. Odvetnik Vilhar je dosegel, da so ustanovili sklad, iz katerega bodo nadarjeno mladino podpirali pri študiju. Zanj so potrebovali denar in Irena je za ta namen darovala skoraj polovico vseh svojih prihrankov.

\subsection{Nasprotja med Cinziino, Alessandrovo in Marcovo materjo}

Cinziina in Alessandrova mati živita v Trstu od nekdaj, medtem ko se je Marcova mati v mesto priselila iz Istre šele po vojni. Alessandrova in Marcova mati živita v revnejšem predelu mesta, Cinziina pa v prestižni mestni četrti. Za razliko od drugih dveh je Cinziina mati vedno lepo urejena in gosposko oblečena. Kljub svojemu višjemu meščanskemu položaju pa iz njenega govorjenja ne razberemo intelektualne plemenitosti, ki jo izžareva njen mož. Obe, Cinziina in 
Alessandrova mati, se počutita v mestu doma. Marcova mati pa se v Trstu ne počuti sprejeta. Živi v revščini in globoki jezi, da je morala zapustiti domače Juricane, kjer je prej živela življenje brez pomanjkanja. Tako se je na poziv starejšega sina, da se ji pridruži na Sardeniji, takoj odzvala. Vsem trem pa je bilo skupno, da so bile sila nestrpne do drugačnih. Vsaka je vedno poudarjala le krivice, ki so se jim zgodile zaradi dejanj drugih narodov ali ras. Tako je Cinziina mati Marcu že na drugem obisku odkrito priznala neodobravanje prihoda istrskih beguncev:

»Nimamo več ladjedelnic, « je povzela žena, »V pristanišču ni nobene ladje, pravice pa dobivajo samo vaši Istrani, /.../ Pa Tržačani? Kdo misli na Tržačane, ki so se rodili in živeli tukaj, komaj so čakali, da so se otresli Avstrije, pa je zdaj pravično, da plačujejo? Brez potrdila o begunstvu si morajo iskati delo v Avstraliji in Kanadi. Vam, Marco, ne bi smelo biti težko, da bi si našli delo pri vseh teh zaščitnih ukrepih, kolikor jih je za vas /.../« (Tomizza 1981: 124)

Tudi Alessandrova mati se je v edini vlogi, ki ji jo literarno besedilo namenja, pokazala za omejeno v svoji miselnosti. Ko jo je nekega dne poklicala Cinziina mati, da bi izvedela kaj več o Marcovem izvoru, je suho zaključila s klasično tržaško frazo, da morajo biti zagotovo ššcavi.

Tudi Marcova mati se ni pokazala za odprto. Popolnoma je odklanjala tako Jude kot Slovane. Kljub temu da z njimi ni imela neposrednih izkušenj, jim ni prizanesla. V svojem razmišljanju je bila pristranska. Njen pogled se razkrije v pogovoru z Marcom:

»Mama, kaj so zate Judje?« Prepričana, da sprašujem za svoj roman, je odgovorila /.../: $»$ To so ljudje, drugačni kot mi. Drugo vero imajo in še v cerkev ne hodijo.« »Zakaj pravijo judovska svinja?«/.../ »Ravno zato, ker ne hodijo v cerkev,« je odvrnila. Izzval sem jo: »Tudi jaz ne hodim v cerkev. /.../ Ti ne bi bilo všeč, če bi se poročil z judovskim dekletom?«/.../ Bolje se je poročati z ljudmi, kot smo mi.« (Tomizza 1981: 94-95)

Ugotovimo lahko, da v konfliktnem povojnem času nobeni ni uspelo premagati obrambne sovražne nastrojenosti do drugih narodnostnih skupin. Vsaka je poudarjala drugačnost kot nekaj sovražnega in nevarnega ali vsaj nadležnega. Bistvene so jim bile le njihove krivice kot končni rezultat. Popolnoma apatične pa so ostajale do krivic in trpljenja drugih.

\subsection{Metafora neuresničenega prijateljstva}

Zgodba o prijateljstvu služi kot okvir za slikovito predstavo o sobivanju dveh nasprotnih elementov. Subtilni detajli, geste, komaj opazni nezaupljivi pogledi, drobna dejanja in besede nam zelo nazorno predstavijo realno obstoječo togo tržaško miselnost, ki jo predstavlja Alessandro, in trden, a odprt slovenski svet na drugi strani. Slednjega zagovarjajo Marcova dejanja in misli. Njegova strpnost predstavlja tanko vez med enimi in drugimi. Njegove plemenite želje ostajajo odprte in nepotešene. Prijatelj kot predstavnik okorele tržaške nestrpnosti ne opusti svojih trmastih stališč in odločno ostaja na strani nasprotnika 
Slovencev. Ob vsakem porazu se njuno prijateljstvo razrahlja in začasno prekine. Ko pa ga zapusti slovensko dekle, je poraz še bolj ponižujoč. Zanj je Irena predstavnica nižjega sloja in nižje narodnosti, skratka pripadnica ljudi, ki so vedno pripravljeni hlapčevati, in se mora tako $\mathrm{v}$ vseh položajih ponižati in prilagoditi. S svojo zavrnitvijo mu ona zlomi ponos. Vez med obema svetovoma mu predstavlja prav prijatelj Marco, ki mu odtlej postane nadležen in odveč. Predstavlja mu nek odmev poraza iz planote, ki jo je v svoji navidezni skromnosti in prijaznosti podcenjeval. Kras ga nepripravljenega za vstop v novo okolje zavrže. Prijateljstvo je tako zaradi slednjega spoznanja ohlajeno in prekinjeno. Poskus iskrenega povezovanja med slovanstvom in italijanstvom ostaja neuresničen. Tako bi lahko povzeli, da je bistvo romana prav v tej vezi med dvema nasprotnima poloma. Neuresničeno prijateljstvo med Marcom in Alessandrom je metafora za še vedno neuresničeno prijateljstvo med obema narodoma. Na podlagi Tomizzevega življenjepisa vemo, da je zgodba del njegovega resničnega življenja. $Z$ dvojno identiteto si je globoko želel, da bi se obe sprti strani začeli sprejemati, vendar se mu želja v času življenja ni uresničila. To žalostno ugotovitev predstavi skozi neuresničeno prijateljstvo dveh drugače mislečih ljudi. Naslov Prijateljstvo je treba razumeti kot razočaranje. Pomen se na koncu namreč pretvori v svoje nasprotje.

Pisatelj v nekem intervjuju žalostno ugotavlja:

/.../ Io forse sono stato un utopista /.../, purtroppo sono stato uno cattivo profeta e forse questa e' la più grande sconfitta morale e personale /.../. Ho visto, che esiste ancora quella barriera e d' e' molto forte /.../ Per qui l' amicizia /.../ e' l' ultima mia speranza, ciò e' le generazioni nuove forse potranno approdare a questo dialogo o questa collaborazione. ${ }^{1}$ (Kovačič 2009)

Pisatelj nam je skozi zgodbo natančno predstavil psihološko podobo predstavnikov določenih tržaških skupin. Žal pa je moral na koncu priznati, da so številni predsodki še zelo živi in da tokrat poskus spoprijateljitve še ne bo mogoč. Podobno v sodobnem času razmišlja pesnik Miroslav Košuta, ko ga v enem od intervjujev iz leta 2011 Marija Pirjevec sprašuje o njegovem pogledu na prihodnost Trsta: »To je tista maligna tvorba, ki je nikakor ne moremo izrezati, dokler se bo podžiganje sovraštva tako bogato obrestovalo /.../, preostane nam upanje, da se bo prej ko slej pojavila na obzorju generacija, ki bo odprla vrata in okna in srca silovitemu prepihu« (Pirjevec 2011: 278).

\section{Tržaška identiteta skozi Marcove oči}

Kot smo ugotovili, Marco ob prihodu v Trst občuti predvsem stisko. Tržačani celo v njegovi zunanji podobi prepoznavajo drugačne poteze. Njegov jezik je

\footnotetext{
${ }^{1}$ »/.../ jaz sem bil mogoče utopist /.../, žal sem bil slab prerok in mogoče je to moj največji poraz na moralni in osebni ravni /.../. Videl sem, da še vedno obstaja tista ovira in ta je zelo močna /.../, zato prijateljstvo /.../ je moje zadnje upanje, torej bodo mogoče nove generacije dosegle ta dialog ali to sodelovanje."
} 
obogaten z istrsko barvitostjo, misli so odprte in ego manj zahteven. Njegova umirjena skromnost trči ob tržaško hrupno vzvišenost. Mesto občuti kot možnost predvsem intelektualnega napredka. Mati pa išče le prejšnjo materialno blaginjo, zato mesto zapusti. Marco je seveda literarno ime za pisatelja Fulvia Tomizzo, ki je vso zgodbo romana Prijateljstvo sam doživel. V več intervjujih poudarja notranjo potrebo po zapisovanju resnice: »Ne zanima me opisovati velikih likov, pač pa preproste ljudi /.../ Literaturo skušam obogatiti z injekcijami /.../ resničnega življenja. Drugi gledajo na življenje skozi literarne parametre /.../, mislim pa, da bi morala literatura posredovati pravo, resnično življenje« (Kemperle 1989: 12). Podobno ugotavlja tudi pesnik Josip Osti, in sicer da »so Tomizzevi romani navadno avtobiografski, ali kot pove v enem izmed njih, pisanje o lastnem življenju /.../« (Osti 2002: 116). Naše trditve lahko podkrepimo še z besedami Cirila Zlobca, dobitnika nagrade Fulvio Tomizza, ki pravi, da so Tomizzo zanimale »človeške usode v njihovem povsem konkretnem življenju, ki pa se skozi pripoved zlivajo že kar v simbolne like (Prijateljstvo, Frančiška) predvsem tistih, ki na tem prostoru živijo drug ob drugem, zelo težko pa /.../ drug z drugim« (Zlobec 2011: 187). Tako so Marcove izjave in izjave nekaterih drugih literarnih likov o Trstu in vzdušju v njem njegove misli. Svoj miselni tok preusmerja v osebnostne odtenke literarnih likov v svojih umetnostnih besedilih. Mesto se mu na začetku zdi tuje, sčasoma pa se Marco vpelje v tržaško mestnost in jo sprejme za svojo, a žal v mestu začuti neko vztrajno uvelost življenja in napredka nasploh. Mesto, zaslepljeno s trmasto zahtevo po strogo čisti italijanski identiteti, začne nazadovati in odganjati napredek.

Nekdanjo mestno svetovljanskost in gospodarski razcvet tako podpirajo le še vse šibkejši temelji, ki se pod težo mestne trme pogrezajo v svojo hrepenečo odprtost na morje. Podobno tudi Tomizza večkrat ugotavlja, da se je »ustavil samo Trst s svojo lenobo, s svojo lagodnostjo in gledanjem nazaj /.../. Trst je umetno mesto, zato je bil tudi vseskozi privilegiran. Sedaj je privilegijev konec« (Kriščak 1995: 13). Trst z Mola Audace z razprtimi očmi išče rešitev, tako kot je počel to naš pesnik moderne Dragotin Kette in to še vedno počnejo »nešteti marci«.

\section{Tržaška hrepeneča duša}

Tomizzevi literarni junaki in Tomizza sam si kljub občasnemu pesimističnemu malodušju predvsem želijo, da bi Trst presegel to zavirajočo miselnost. O tem občutju izgubljenosti veliko piše v svoji knjigi tudi pisateljica Jan Morris:

Zbuja mi hrepeneč užitek /.../, nekaj nasladnega je v tem občutku, kot poželenje nun po njihovem Bogu. Je to latentni religiozni instinkt ali pa samo brezdanje pričakovanje Trsta, zaradi katerega vedno iščem nekaj veličastnega, kar se bo še zgodilo? Morda v tem mestu zeva vsi čutijo tako. (Morris 2011: 153)

Podobna občutja melanholije, pomešane z vero v neko ponovno vstajenje Trsta, občutijo vsi Tržačani, ne le pripadniki manjšin. Mesto je s svojo nestrp- 
no držo izgubilo veliko prave vsebine. Tako postaja oz. ostaja, kot ga imenuje pesnik Miroslav Košuta, »Trieste triste «. ${ }^{2}$ Kljub vsemu še živi in upanje v lepšo prihodnost še obstaja. Upanje gojijo številni prebivalci mesta, ki aktivno delajo na duhovnem in intelektualnem oplemenitenju Trsta. Zdi se, da je ta namen zelo dobro opravil tudi Tomizza skozi literarno ustvarjanje. Vse je sporočal v tišini, skozi literaturo, ki je le podajala dejstva skozi oči manjšinca. Kljub njegovi tišini pa je njegov namen obrodil sadove in prispeval k razrahljanju marsikaterega dotlej trdovratnega predsodka, saj so bile nekatere njegove knjige, npr. Frančiška, na lestvici najbolj prodajanih knjig v Italiji. Metaforično bi lahko rekli, da Trst ostaja živ ali celo živahen gospod, vendar s krvavečim srcem, ki ga vdano zakriva za debelo obvezo. Nad njim bdi nešteto nevidnih oči in ga svari, naj vztraja v svoji lažni resnici in taji bolečino. Je pa tudi veliko lepših izkušenj in tako Miran Košuta (1996: 19) ugotavlja, da se kljub vsem manj veselim trenutkom nad mestom nebo tudi odkrije: »Nebo je, ko te italijanski veleposlanik v Kopru vpraša za slovensko slovnico in vadnico«.

\section{Zaključek}

Ugotovili smo, da Tomizzeva literatura v ospredje postavlja predvsem stisko marginaliziranih ljudi, ki brez večjih možnosti upora prenašajo večni občutek manjvrednosti. Prvi skupini ljudi očita vzvišenost in neutemeljen ponos, ki v stiku s predstavniki druge skupine sprožata nelagodna občutja in konflikte. S svojim trmastim vztrajanjem pri spoštovanju le ene, predvsem italijansko-meščanske identitete, vzdržujejo in spodbujajo nastanek vse večjega prepada med obema skupinama. Avtor se ves čas postavlja na stran manjšincev.

Sklenemo lahko, da je bilo Tomizzevo temeljno načelo pri literarnem ustvarjanju povezovanje Slovencev in Italijanov. Poskus ustvarjanja harmoničnega sobivanja obeh narodov, ki že stoletja živita na istem prostoru in ju naravno ločuje le jezikovna razlika, ki pa ne bi smela predstavljati ovire pri vsesplošnem sodelovanju.

Tomizza je vedno zagovarjal, da meja ne bi smelo biti, da bi človek v človeku moral iskati predvsem brata in prijatelja. Za vse to pa je potrebna predvsem velika mera spoštovanja, ki bi morala postati nekaj naravnega. Podobno izpostavlja višje vrednote človeštva pobudnik ustanovitve Foruma Tomizza Milan Rakovec, ko v članku razmišlja o manjšinstvu: „Nemara nam uspe naš stari kontinent kolikor toliko harmonizirati. Če namesto domoljublja izberemo človekoljubje« (Rakovec 2012: 3). Za uresničitev tega je nujno sodelovanje obeh strani, slovenske in italijanske. Ob tej ugotovitvi nam dajejo upanje besede Milana Rakovca, ki je eden od glasnikov in nadaljevalcev dela v Tomizzevem duhu:

Tomizza je kot mojster, učitelj nove /.../ osvobojene istrske kulture /.../ kulture siromakov /.../ naredil to, da so mnogi od nas nadaljevali po njegovi poti. /.../ In tudi jaz sem napisal nekatere stvari v tem duhu. (Rakovec, 2011)

\footnotetext{
${ }^{2}$ Trieste triste (Žalostni Trst) je naslov pesmi Miroslava Košute.
} 
Zaključimo lahko, da sta Tomizzevi metafori o uresničitvi ljubezni med Slovenci in Italijani v romanu Frančiška ter metafora o dotlej neuresničenem prijateljstvu med obema narodoma v romanu Prijateljstvo še vedno aktualni. Zagotovo bi nam morali služiti kot opozorilo, da je dela na tem področju še veliko in da potrebujemo ljudi odprtih misli, ki bi Tomizzevo delo lahko nadaljevali. Sklenemo lahko, da ima Tomizzev literarni opus veliko vrednost tudi za življenje samo, saj so bila njegova temeljna literarna dela prežeta pretežno $\mathrm{z}$ vedno aktualnim vprašanjem čiste identitete, ki je tudi globalni problem, v obravnavanih literarnih delih pa je lokalno definiran.

\section{VIRI IN LITERATURA}

Marta IVAŠIČ, 2010: Lessico familiare: L'uso delle parole quando si parla di storia. Frontiere invisibili? Storie di confine e storie di convivenza. Ur. Vinci A. M. Trst: Edizioni Universita' di Trieste. 30-40.

Stane JUŽNIČ, 1993: Identiteta. Ljubljana: Fakulteta za družbene vede.

Majda KAUČIČ BAŠA, 2007: Ohranjanje slovenščine med Slovenci na Tržaškem. Živeti mejo. Ur. Miran Košuta. Trst: Slavistično društvo Slovenije. (Zbornik Slavističnega društva Slovenije, 18). 193-20.

Marjan KEMPERLE, 1982: Tomizza o Dedinji, Mladoporočencih in še kom. Primorski dnevnik 18, 22. 1. 1989.

Miran KOŠUTA, 1996: Krpanova sol. Ljubljana: Cankarjeva založba.

- -, 2002: Ljubiti Frančiško. Primorska srečanja 257/258, 38-41.

Ketty KOVAČIČ POLDRUGOVAC, 2009: Spezzoni d' archivio. Pridobljeno 1. 9. 2011, http://tvslo.si/predvajaj/tomizza/ava2.76591268/

Kaja KRALJEVIČ, 2012: Pravičnost, upognjena pod profitom izgublja tla pod nogami. Pridobljano 3. 7. 2012, http://www.mambo.si/video/260099-pravicnost-upognjena-pod-profitom-izgublja-tla

Jan MORRIS, 2011: Trst in kaj pomeni nikjer. (Prevedla Staša Grahek.) Ljubljana: Cankarjeva založba.

Josip OSTI, 2002: Slovenci v prozi Fulvia Tomizze. Sodobnost 1, 115-120.

Marija PIRJEVEC, 2011: Tržaški književni razgledi. Trst: Mladika.

Milan RAKOVEC, 2012: Vsi smo manjšinci. Primorske novice 15, 19. 1. 2012.

Gian Antonio STELLA, 1992: Pogovor s Fulviom Tomizzo po srcu Italijan, po duši Slovan. Primorska srečanja 128/129, 11-15.

Ana TOROŠ, 2011: Podoba Trsta in Tržaškega v slovenski in italijanski poeziji prve polovice 20. stoletja. Nova Gorica: Univerza v Novi Gorici.

Fulvio TOMIZZA, 2002: Frančiška. (Prevedel Miran Košuta.) Trst: Založništvo tržaškega tiska. 
- -, 1981: Prijateljstvo. (Prevedel Jože Stabej.) Ljubljana: Državna založba Slovenije. Razmišljanja o pravici kot o iluziji ali utopiji. Primorski dnevnik 121, 24. 5. 2012.

Ciril ZLOBEC, 2011: Vse daljave niso daleč. Ur. Alina Carli in Martina Kafol. Trst: Založništvo tržaškega tiska. 187-188.

THE MOTIF OF IDENTITY IN FULVIO TOMIZZA'S NOVELS FRANČIŠKA AND PRIJATELJSTVO

The discussion presents the motif of identity in the novels Frančiška and Prijateljstvo written by the Istrian writer Fulvio Tomizza. The identity of the major literary characters, Marco and Frančiška, is exposed through the stories of both novels. Their identity is special because both of them are immigrants in Trieste. They are distinguished from other inhabitants of the city by ethnic and social affiliation. Marco is an Istrian and feels an equal member of three nationalities - Italian, Slovene, and Croatian. Frančiška is a Slovenian in intolerant postwar Trieste. Due to geographical and historical determinism Trieste is tolerant only to pure Italian identity. All the other identities are foreign and hostile. So Frančiška as a Slovenian and Marco as an Istrian are undefined newcomers and foreigners. They feel alienated also because of social identity. In particular, they both come from poor rural communities. The city, on the other hand, requires a different posture. Also the comparisons of identities of other literary characters are based on the opposites between Slav - Italian, provincial man - townman, critical scholar - simple, healthy farmer. The novels reflect also autobiographical elements, especially in the novel Prijateljstvo, which talks about the Tomizza's real life experience. The author's fundamental principle of literary creation is the integration of Slovenes and Italians. With his sheer persistence in achieving peace and mutual acceptance, Tomizza has always stressed solidarity, openness, honesty, trust, and the need for cooperation from both sides, Italian and Slovenian. 